\title{
MODERNISME DAN REFORMISME DALAM PEMBINAAN \\ HUKUM ISLAM \\ DAN PRANATA SOSIAL
}

\author{
Bahdar \\ STAIN Datokarama Palu Jl .Diponegoro No. 23 Palu \\ E-mail:bahdar@yahoo.co.id
}

\begin{abstract}
Abstrak. Tulisan ini memaparkan modernisme dan reformisme dalam pembinaan hukum Islam dan pranata sosial. Kajian ini diarahkan kepada eksistensi hukum Islam di tengah perubahan sosial. Hukum Islam yang bersifat abadi yang dihadapkan dengan realitas sosial masyarakat selalu berubah, telah menarik perhatian yang serius pada kebanyakan para ahli ilmu. Hal yang menjadi perdebatan di antara para sarjana orientalis adalah soal adaptabilitas hukum Islam dengan lingkungan perkembangan sosial masyarakat. Masyarakat selalu berubah mengikuti perubahan waktu dan tempat, sementara hukum syariah sifatnya final dan abadi. Berkaitan dengan masalah tersebut, maka yang patut dipertanyakan adalah apakah hukum Islam itu bisa dikembangkan dan dapat mengakomodasi kepentingan umat manusia yang selalu bergerak maju, atau hanya mengikuti keabadian yang ditetapkan Tuhan.
\end{abstract}

Abstract. This paper describes the development of modernism and reformism in Islamic law and social institutions. This study is directed to the existence of Islamic law in the midst of social change. Islamic law is eternal is faced with an ever-changing social reality, has attracted serious attention in many scientific experts. It is a debate among scholars orientalis is about environmental adaptability of Islamic law with the social development of society. Society always change with the change of time and place, while sharia law final and eternal nature. In connection with the issue, it is questionable whether Islamic law can be developed and can accommodate the interests of humanity that is always moving forward. Or whether only follow God set eternity.

Kata kunci: modernisme, reformisme, hukum Islam, pranata sosial 


\section{PENDAHULUAN}

Diskursus mengenai perkembangan hukum Islam telah lama menjadi kajian para sejarawan Barat terutama yang berkepentingan untuk melakukan justifikasi terhadap keontetikan hukum Islam.Karena tema hukum memiliki hubungan dengan realitas dan lingkungan fisik, maka mau tidak mau harus menghadapi tantangan-tangan yang berkaitan dengan kenyataan perubahan sosial. ${ }^{1}$

Hukum Islam selalu didefenisikan sebagai hukum yang bersifat religius dan suci, yang karenanya menjadi hukum yang bersifat abadi.Maka persoalan yang selalu diperdebatkan di kalangan orientalis adalah mengenai adaptabilitas hukum Islam dalam menghadapi tantangan perubahan.

Merupakan fenomena yang menarik dan dapat menyampaikan fakta yang sangat padat, ketika agama berinterkasi langsung dengan modernitas dalam berbagai wujudnya,. Oleh karena sifat agama yang primardial sebagai divine order (al-hukm al ilahy) namun sekaligus selalu compatible dengan tanpa batas ruang dan waktu (Șālih i kulli zaman wa makan) bagi kehidupan manusia.Sebagai agama teologis, Islam merupakan sistem nilai dan ajaran yang bersifat ilahiya, transeden, dan absolut, namun dari sisi sosilogis ia merupakan fenomena kultural dan realitas sosial dalam kehidupan manusia. Dalam realitas sosial, Islam tidak lagi sekedar kumpulan doktrin yang bersifat universal, namun juga mengejawantahkan diri dalam institusi sosial yang dipengaruhi oleh situasi dan dinamika ruang dan waktu. ${ }^{2}$

Di antara perdebatan yang menarik soal adaptabilitas hukum Islam dengan lingkungan perkembangan sosial yang sering menjadi titik pangkal pertanyaan adalah mengenai otoritas

\footnotetext{
${ }^{1}$ W.Priedman, Law In A Changing Society (London:Pelien,984),h.19

${ }^{2}$ Azyumardi Azra, Pergolakan Politik Islam: Dari Fundamentalisme, Modernisme Hingga Post Modernisme (Jakarta: Paramadina,199),h.1
} 
akal yang dimiliki manusia di hadapan teks syariah.Otoritas akal menjadi krusial ketika dihadapkan dengan kemutlakkan otoritas syari' dalam menetapkan hukum Islam, hukum syara' hanya ada di tangan Allah. ${ }^{3}$ Namun secara tegas pula ada ketentuan teks syariah yang lain yang memberikan sebagai otoritas penetapan hukum kepada mujtahid. ${ }^{4}$ Hal ini telah menimbulkan banyak kesalahpahaman antara sarjana muslim dan non muslim dalam memandang fleksibelitas dan progresifitas hukum Islam sebagai produk ulama (juris law) dan keutuhan syariah dalamresistensi kewahyuan (divine law). ${ }^{5}$ Ditambah dengan beragam kritik tentang metodologi sebagai basis penetapan hukum Islam yang sudah out of date. ${ }^{6}$ Dengan berbagai faktornya, baik yang datang dri individu yang tidak memahami secara holistik metodologi hukum Islam maupun memang disebabkan kekurangcanggihan logika sains yang dirancang dalam sturuktur metodologis meskipun bukan berarti tuduhan itu dapat ditanggapi dengan taken for granted, namun harus diakui bahwa hal tersebut adalah sebuah realita kegelisahan intelektual ketika ditanya tidak menemukan jawaban yang sifnifikan.Wacana semacam ini sebenarnya telah muncul ketika terjadi tarik menarik antara kelompok rasionalis (ahl al-ra'y) dan teksulis tradisionalis (ahl alhadīis).

Ada dua pandangan dalam rangkan menjawab pertanyaan tersebut, pertama, yang dipegangi oleh sejumlah besar Islamolog seperti C. Snuck Hurgronje. ${ }^{7}$ Dan kembanyakan jurist muslim tradisionalis yang melandaskan pemikirannya pada hadis (hadis oriented) mempertahankan pendapat bahwa dalam konsepnya, dan menurut sifat perkembangan dan metodologinya, hukum

${ }^{3}$ QS.Al An'am: 57; Yusuf: 40,67

${ }^{4}$ QS.4: $105.10: 24$

${ }^{5}$ The Muslim World (T.Th.1966),h. 13

${ }^{6}$ Akh,Minhaji, Reorientasi Kajian Ushul Fikih' ( Al Jamiah,T.Th),h.12

${ }^{7}$ R.Stephent Humpherys, Islamic History, Framework for Inquiry ( Princeton Univesity Press,1992),h. 24 
Islam adalah abadi dan karenanya tidak bisa beradaptasi dengan perubahan sosial. $^{8}$

Pandangan kedua, yang dipegangi oleh sejumlah Islamolog seperti Y. Linant de Bellefonds dan mayoritas reformis dari Jurist Islam, seperti Subhi Mahmassani, berpendapat bahwa prinsipprinsip hukum Islam dalam praktek dan penekakanan pada ijtihad (independent legal reasoning) cukup menunjukkan bahwa hukum Islam bisa beradabtasi dengan perubahan sosial. ${ }^{9}$ Pandangan ini yang dipahami oleh sebagian besar pemikir dan penulis kitab dalam metodologi hukum Islam yang memasukkan materi tersebut dalam kitabnya, kecuali kelompok Zahiriyah, sebagian besar Syiah dan sebagian besar Hanabillah.

Demikianlah hukum Islam diperdebatkan dalam segala aspeknya, termasuk awal sejarah perkembangannya. ${ }^{10}$ Materinya dan legalisasi sumber hukumnya.

Dari uraian latar belakang di atas, maka yang menjadi persoalan dalam kajian adalah: dapatkah hukum Islam itu dikembangkan oleh akal pikir manusia atau hukum Islam hanya mengikuti keabadian yang ditetapkan oleh Tuhan? Alat apa yang digunakan untuk mengembangkan hukum Islam itu?

\section{DINAMIKA PEMIKIRAN HUKUM ISLAM}

Dari sudut pandang kesejarahan, perkembangan hukum Islam pada priode klasik dan pertengahan sangat dinamis, bahkan cenderung fluktuatif, dimana perubahan, perkembangan dan masa kejayaan diraih pada masa ini. Demikian juga pada masa ini hukum Islam berhasil mencapai pucak kejayaan dan dinamikanya.

${ }^{8}$ Muhammad Khalid Mas'ud, Filsafat Hukum Islam dan Perubahan Sosial. Diterjemahkan oleh : Yudian W.Aswin ( Surabaya: Al Ihlas, 1995 ),h.2324

${ }^{9}$ C.H.Hurgronje, Selected Work (Laiden:E.J.Briil,1957),h. 23

${ }^{10} \mathrm{Ibid}$, 
Jika diamati Khudhari Bik misalnya. ${ }^{11}$ Mencatat dinamika ini dalam enam bagian, dimulai dengan corak pengkajian alquran pada masa mufassir yang mencatatkan pemahamannya terhadap teks Alquran dan diakhiri dengan munculnya kebutuhan pengkajian hadis atau sunnah sebagai salah satu bgian sumber hukum Islam setelah banyak kasus belum dapat dipecahkan melalui teks Alquran sampai pada masa tabi'in, yang menghasilkan figur dan profil mujtahid di samping ufassir juga para muhaddis yang tetap berkarya sepanjang kurun sejarah bahkan sampai masa modrn.

Abad ketiga dan keempat diwarnai dengan maraknya pengkajian agama Islam dalam sistematika yang baru kemudian disebut sebagai fikih dan merupakan jabaran praktis dari ajaran agama yang bersumber dari Alquran dan sunnah, maka produk mujtahidnya pun adalah para fukaha dan teritis hukum Islam sampai masa kebesaran fiki, dan diakhiri dengan trend mengikuti dan mempertajam mazhab ulam fikih masa awal yang disebut dengan istilah antara taqlid atau minimal ittiba'.Situs taqlid inipun dapat dibuktikan dengan banyaknya kitab yang secara berulang-ulang menjelaskan pendirian suatu mazdhab fikih dalam bentuk syarah, hasyyyah dan lain-lain.

Masa itulah yang paling tidak menjadi faktor penting yang menyembabkan deklinasi dan mengakhiri masa kebesaran fiki( sering disebut masa jumud an fikih).sampai akhir masa pertengahan, dimana banyak negara muslim atau bekas negara muslim yang mengambil sikap resepsi atau resistensi terhadap kebudayaan yang berkembang dan eksis pada masa itu. ${ }^{12}$ Resepsi tau resistensi terhadap budaya, tradisi,dan metodologi dari luar itu sebenarnya merupakan upaya resepsi mazhabnya dari ancaman konsep lain.Adapaun pertimbangan yang diberikan

\footnotetext{
${ }^{11}$ Fazlurrahman, Islam ( Chicago: Thucago University Press, 1979), h. 91

${ }^{12}$ Bassam Tibi, Islam and The Cultural Accomodation of Social Change, diterjemahkan dengan judul Islam Kebudayaan dan Perubahan Sosial (Yogyakarta: Tiara Wancana,1999), h. 110-120
} 
dalam rangka resepsi atau resistensi itu semua ternyata memiliki rujukan dan analogi rasional dengan teks alquran maupun sunnah.

\section{ALQURAN, SUNNAH DAN TERBENTUKAN FIKIH}

Pada akat konsepsi hukum Islam, terletak ide bahwa hukum esensinya religius dan berjalin berkelindan secara religius.Itulah sebabnya sejak awal mula sejarah Islam, hukum sudah dipandang bersumber dari syariah(pola prilaku yang diberikan Tuhan untuk menjadi tuntunan bagi manusia), karena itu hukum haruslah berdasarkan wahyu Ilahi.Alquran sebagai wahyu yang paling lengkap,haruslah dipakai sebagai pedoman utama, bahkan satusatunya bagi kehidupan dan sebagai sumber hukum. ${ }^{13}$

Kumpulan pernyataan Alquran adalah universal dan konkrit.Di samping menanamkan prinsip-prinsip moral dan spritual yang langgeng dia juga menjadi pedoman bagi Muhammad saw. dan masyarakat Muslim dalam menjalankan segala aktifitas sosial dan hukum sejak awal pertumbuhan Islam. ${ }^{14}$ Legalisasi Alquran diawal perkembangan Islam di Madinah, hanyalah menyempurnakan hal-hal tertentu dari hukum adat yang telah ada sebelumnya dan bukan menggantikannya secara keseluruhan. ${ }^{15}$ Sebagaimana legalisasi Alquran yang pertama ditunjukan untuk membenai sistem kepemimpinan yaitu dengan memperkenalkan sebuah otoritas politik baru dengan kekuasaan legislatif.Kemudian selanjutnya, dari evolusi kepemimpinan tersebut, beranjak pada porses pembuatan undang-undang secara teknis, ukuran-ukuran hak dan kewajiban serta, perangkat untuk menanggulangi pelanggaran hak dan kewajiban tersebut. ${ }^{16}$ Setelah itu barulah nabi Muhammad saw. memainkan peranya sebagai legislator politik.

${ }^{13} \mathrm{Ibid}$,

${ }^{14}$ N.J.Coulson, A history of Islamic law ( Edinburg, The University Press,1979),h. 91

${ }^{15}$ Ibid, h. 11

${ }^{16}$ Ibid,h. 16 
Pada masa awal Islam syariah ( yang pada saat itu belum ada diskurus mengenai erbedaan terminologi antara fiki, syariah atau agama dan lain-lain) dibentuk melalui pemahaman terhadap teks Alquran dan Sunnah. ${ }^{17}$ Semua persoalan hukum selalu berpulang pada dua kedua teks wahyu Ilahi. Semua produk hukum yang bersumber dari keduanya disamaratakan dengan syariah.Kondisi ini sangat mapan, sampai tiba masa perkembangan aliran kalam/teologi yang membuka front pertentangan dua kutub antara mempertahankan kemapanan persepsi keabadian Alquran dan kemakhlukan Alquran, yang kemudian dua kelompok tersebut diidentifikasi sebagai perbedaan antara sunni dan Mu'tazilah.

Dengan berbagai catatan reformasi pranata sosialnya Alquran telah menggeser beberapa aturan bermasyarakat yang berlaku pada masyarakat Arab sebelumnya. Seperti aturan mahar perkawinan, 'iddah wanita yang dicerai, aturan pengangkatan anak dan konsekuensi hukumnya, dan lain-lain. Meskipun demikian legislasi Alquran pada masa awal ini tidak luput dari kritik Coulson yang memandang legislasi Alquran hanyalah menegakan perubahan-perubahan terhadap hal-hal tertentu dari hukum adat Arab yang ada dan bukannya merubah sistem hukum secara keseluruhan. ${ }^{18}$ Aturan-aturan yang diturunkan untuk menjawab berbagai kasus yang melatarbelakangi (sabab al-nuzul) telah mengakibatkan ketidakterpaduan sistematika legislasi Alquran. Meskipun demikian hal itu tidak menyurutkan semangat umat Islam dalam mengkaji menjadikan pedoman dan meneladani segenap aturan dan petunjuk Alquran, bahkan Alquran dipandang sebagai kitab hukum yang telah lengkap dan mampu menjawab berbagai tantangan dan persoalan yang terus berjalan.

\footnotetext{
${ }^{17}$ QS.An Nisa ayat 59 dan dialog antara Rasulullah saw.dengan Muadz bin Jabal ketika diutus ke Yaman sebagai Qadhi.

${ }^{18}$ N.J.Coulson, A History of Islamic Law ( Edinburg, The University Press, 1979), h.9-20
} 
Dalam konteks itulah muncul perdebatan sengit seputar eksistensi Alquran bagi umat Islam dan persepsi umat Islam tentang Alquran. Bernard Weiss mencatat bahwa Mu'tazilah pernah berusaha memberikan rasionalisasi kemakhlukkan Alquran dengan menyebut konstruksi huruf, suku kata, lafal dan kalimat sebagai pembuktian kemakhlukkannya. Namun Sunni bersikukuh pada pendapat keabadian wahyu Ilahi tersebut. Pengakuan mayoritas ulama muslim terhadap doktrin Sunnidan kekalahan Mu'tazilah dalam hal ini telah melahirkan kesimpulan bahwa secara judisial maupun legislatif syariah atau hukum Islam keberadaannya bersifat independen dan tidak terkait dengan kawasan perkembangan pemikiran manusia, karena wahyu itu sifatnya melampaui batas ruang dan waktu. ${ }^{19}$

Sedangkan studi hadis dalam kaitannya dengan perkembangan hukum Islam telah menjadi sasaran utama kedua jika tidak lagi ditemukan aturannya dalam Alquran. Kedudukan ini dapat diberlakukan sebagai pengisi ketiadaan hukum, pelengkap kekurangan, perincian atas yang global, spesifikasi atas yang umum, dari yang ada dalam Alquran.

Karena kedudukannya yang demikian kuat maka dalam catatan Hallaq, epistemologi, proses dan stndar keabsahan transmisi, dan kritik dan uji otentitasnya merupakan corak studi hadis masa awal. ${ }^{20}$

Dalam mencoba memperoleh solusi atas berbagai kasus hukum, ahli fikih dihadapkan pada teks yang menjadi refrensinya yang terakhir. Kedudukan teks dalam menemukan hukum semacam itu pula yang telah memicu perkembangan studi bahasa sangat gencar. Bahasa hukum telah diklasifikasikan sedemikian rupa bertingakat dan membawa implikasi yang beragam terhadap

\footnotetext{
${ }^{19}$ Bernard Weiss, Exotericism And Objectivity in Islamic Jurisprudence, In Nicholas Heer (Eds)Islamic Law and Jurisprudence ( 1990), h. 53

${ }^{20}$ Wae B.Hallaq, Sejarah Teori Hukum Islam Pengantar untuk Usul al Fiqh Madzhab Sunni ( Jakarta::PT.Raja Grafindo Persada,2000), h. 88-99
} 
model dan intensitas ikatan hukumnya. Implikasi terkuat dalam studi hukum Islam dari kedua teks syariah ini adalah berlakunya konsep qaț'ī dalam wilayah studinya.

\section{BERBAGAI WACANA TENTANG TEORI HUKUM ISLAM}

Corak pemikiran hukum Islam, sangat dipengaruhi oleh pemikiran teologi.Sebagaimana yang diungkapkan Bernard Weiss, bahwa hukum memiliki sifat keabadian sebagaimana wahyu atau Alquran. Hukum,menurut para fakih telah ada sebelum makhluk yang lainnya ada,karena dia abadi, tanpa awal dan tanpa akhir.Jadi posisi hukum dalam metaforanya menyatu dengan Tuhan, yang keberadaannya melampaui ruang dan waktu,dengan demikian dapat dikatakan bahwa teologi Islam,memberi dasar filosofis bagi yurisprudensi Islam.

Hal ini juga dikatakan Wael B. Hallaq, bahwa hukum itu berasal dari induk ilmu yaitu teologi, karena fungsi teologi adalah membuktikan keberadaan Allah, sifat-sifatNya, wahyu, kenabian, dan semua dasar-dasar agama. Pembahasan ini hanyalah merupakan bagian dari pemahaman hukum Islam tinjauan epstemologi, sedangkan teori hukum Islam, mencakup bahasan yang sangat luas.

Teori hukum Islam, awalnya hanyalah merupakan istinbāt individual para ulama, dan kemudian para ulama mengelompok sehingga lahir mazhab Madinah dan Kufa, yang mana mazhab Madinah lebih menekankan pada tradisi Rasulullah saw. atau sunnah, yang pada perkembangannya kemudian melibatkan peran akan dengan menggunakan metode analogi dan kemudian terkenal dengan qiyas. Sedangkan mazhab Kufa lebih menekankan pada akal dari pada sunnah, memberi kebebasan lebih longgar terhadap peranan akal, dan lebih menekankan 
pertimbangan kemaslahatan, yang kemudian metode ini disebut istihsān, dengan tokohnya Imam Abu Hanifah. ${ }^{21}$

Pada akhir abad kedua dan awal abad ketiga muncul tokoh legendaris yang memberikan penekanan pada konsep teori istinbāt hukum secara lebih komprehensif. Meskipun karya ini masih terlihat berserakan dan belum sistematis, namun karya ini memberikan sumbangan yang luar biasa bagi pertumbuhan ilmu usul fikih, sehingga dia dianggap sebagi arsiteknya ilmu usul fikih, tokoh ini adalah Muhammad Ibn Idris Al-Syāfi'ī dalam karyanya al-Risālah.

Lain halnya dengan Wael B. Hallaq dia menyangkal peranan al-Syāfi'̄̄ yang terlampau diagungkan. Dia memberikan alasan dengan adanya kekurangsempurnaan Kitab al-Risālah, jika disesuaikan dengan syarat metodologis sebuah keilmuan. Akan tetapi dia lebih menekankan keunggulan karya-karya usul fikih yang lahir pada abad kelima Hijiriyah, yang dinyatakan sebagai status spesial dalam aspek usul fikih. Berbeda dengan struktur usul fiki Imam al-Syafi'ī yang bersifat dasar dan agak serampangan, teori-teori pada abad kelima hijiriyah ini memperlihatkan kesadaran yang tajam terhadap struktur, dimana dalam sebuah struktur tertentu topik-topik disusun atau dihubungkan satu dengan lainnya secara sistematis. Demikian juga cakupan bahasannya sudah lebih lengkap dan matang, meliputi epistemologi, norma-norma hukum, bahasa hukum dengan semua macamnya dan cara melakukan uji validasinya, implikasi linguistik, penggunaan teori nāsikh dan mansūkh.

\section{PRODUK INDUKSI TEKSTUAL NORMATIF}

Ketika telaah tekstual terhadap sumber hukum Islam dalam hal ini alquran dan Sunnah memasuki babak akhir, maka hasil telaah tersebut menghajatkan label yang menggambarkan

\footnotetext{
${ }^{21}$ N.J.Coulson, A History of Islamic Law ( Edinburg, The University Press, 1979),h. 122
} 
intensitas berlakunya ikatan hukum yang dikandung teks, yang dalam bahasa usul fikhi disebut dengan khițāb. Khițāb juga yang akhirnya dirumuskan sebagai kata kunci untuk membentuk terminologi ikatan hukum Allah terhadap hambaNya yang dikenal dengan sebutan al-aḥkām al-taklïfiyyah.

Terdapat perbedaan di kalangan ulama fikih dalam membuat ketegorisasi norma-norma hukum tersebut. Usul fikih al-Syāfi'̄ yang kemudian diikuti oleh jumhur ulama fikih merumuskan lima kategori hukum, yaitu: wajib, sunnah, mubah, makruh dan haram. Sedangkan ulama mazhab Hanafi mengkategorikan norma hukum ini dalam delapan kelompok yaitu: farḍ, wājib, sunnah, mustạhabbah, mubāḥ, makrūh tanzīh, makrūh tahrīm, dan harām.

Kategori-kategori tersebut merupakan produk induksi terhadap teks dan redaksi serta implikasi ikatan perintah, larangan atau sikap dua sumber pokok hukum Islam Alquran dan Sunnah yang kemudian dirumuskan dalam ragam kelompok tersebut. Maka telaah tekstual yang lebih detil dan rinci sebagaimana dilakukan oleh imam Hanafi akan menghasilkan produk yang lebih rinci, demikian juga sebaliknya.

\section{PERKEMBANGAN EPISTEMOLOGI}

Al-Jabiri menyebut perkembangan pemikiran fikih Islam dalam dua karakter. Karakter pertama adalah yang disebut dengan fiqh 'amalī yaitu saat mana hukum Islam dipandang sebagai norma-norma keyakinan, kehidupan dan peribadatan yang bersifat praktis yang berlangsung pada masa sebelum fikih menjadi sebuah ilmu yang memiliki sistematika dan teori tersendiri. Sedangkan karakter kedua adalah fiqh nazarī yang mana hukum Islam telah berkembang menjadi pembahasan teoritik yang di dapat diperdebatkan dan terbuka kemungkinan ikhtilaf yang berlipat apa lagi setelah munculnya metodologi fikih. 
Persoalan epistemologi muncul ketika kebenaran hukum Islam yang merupakan bagian dari syariah ternyata mengandung sifat zanni. Sementara sebagaimana dalam catatan Weiss di awal pembicaraan ini telah dinyatakan bahwa sumber syariah bersifat eternal, pemaknaannya bersifat qațī. Maka kebenaran fikih harus terbagi dalam bingkai yang dibatasi oleh hadd atau batasan defenisi, kehadirannya dapat menicayakan hadirnya "yang didefinisikan", demikian juga sebaliknya. Dalam usul fikih hal ini akan sangat kuat terasa pengaruhnya ketika berdiskusi mengenai kekuatan keterlibatan illat dalam penetapan dan penolakan hukum.

\section{PENUTUP}

Dari paparan tulisan ini, dapat disimpulkan bahwa: pertama, Hukum Islam dapat dikembangkan melalui kekuatan akal manusia, karena ayat itu sendiri mengandung qațî̀ dan zannī. Kedua, alat yang dapat digunakan oleh manusia dalam mengembangkan hukum Islam adalah ijtihad dengan menggunakan rasio yang dilengkapi dengan alat metodologis keilmuan sehingga hasil yang didapatkan bisa dipertanggung jawabkan secara ilmiah.

\section{DAFTAR PUSTAKA}

Abū Zahra, Muḥammad, Ușūl al-Fiqh, Kairo: Dār al-Fikr al'Arabiy, 1958

Al-Mīdī, Saifuddin, Al-Iḥkam fī Ușūl al-ạ̣kām, Jilid I, Kairo: Mațaba'ah al-Ma'ārif,1914

Al-Jabiri, Muḥammad 'Ābid, Takwīn al-Aql al-'arabī, Beirut: Markaz Dirāsat al-Wahdah al-'Arabiyyah, 1989

Al-Khatib, Muhammad Ajjaj, Ușūl al-Hadīs 'Ulūmuh wa Mușțalāhuh, Beirut: Dar al-Fikr,1989

Al-Syaukani, Irsyād Al-Fuhūl, Beirut: Dar Al-fikr,t.th. 
Anderson, J.N.D. Islamic Law Modern Wold,New York:New York University Press,1959

Arfa, Faisar Ananda, Sejarah Pembentukan Hukum Islam Studi Kritis Tentang Hukum Islam di Barat, Jakarta: Pustaka Firdaus, 1996

Azra, Azyumardi, Pergolakan Politik Islam: Dari Fundamentalisme, Modernisme Hingga Post Modernisme, Jakarta: Paramadina, 1996

Bassam Tibi, Islam and The Cultural Accomodation of Social Change, diterjemahkan dengan judul Islam Kebudayaan dan Perubahan Sosial (Yogyakarta: Tiara Wancana,1999)

Bik, Muhammad Khudari, Tārikh al-Tasyrī’ al-Islāmī, Beirut: Dār al-Fikr, 1967

Coulson, Noel J., A History of Islamic Law, Edinburgh: Edinburgh University Press,1964

Goldziher, Ignas, On The Development of Haditsh, dalam Moslem Studies ,II, 1997 